\title{
Bisma: Jurnal Bisnis dan Manajemen
}

\author{
https://jurnal.unej.ac.id/index.php/BISMA
}

Vol. 14 No. 2, 2020, Hal. 125 - 132

\section{PENGELOLAAN KEUANGAN, STRATEGI PEMASARAN, DAN JIWA KEWIRAUSAHAAN UNTUK MENCAPAI KEUNGGULAN BERSAING}

\author{
Ni Made Rai Juniariani' ${ }^{1}$, Ketut Puja Wirya Sanjaya ${ }^{2,}$ Ni Putu Sri Mariyatni ${ }^{3}$ \\ Fakultas Ekonomi dan Bisnis, Universitas Warmadewa, Denpasar
}

\begin{abstract}
Abstrak $\mid$ Penelitian ini bertujuan untuk menganalisis pengaruh pengelolaan keuangan dan strategi pemasaran pada keunggulan bersaing, serta menganalisis bagaimana pengaruh moderasi jiwa kewirausahaan terhadap pengaruh dari strategi pemasaran dan pengelolaan keuangan pada keunggulan bersaing. Penelitian ini menggunakan sampel yaitu 76 UMKM yang berada di Denpasar yang ditentukan menggunakan simple random sampling. Teknik analisis data yang digunakan adalah Moderated Regression Analysis. Hasil penelitian menunjukkan bahwa pengelolaan keuangan dan strategi pemasaran berpengaruh pada keunggulan bersaing serta jiwa kewirausahaan mampu memperkuat pengaruh pengelolaan keuangan dan strategi pemasaran pada keunggulan bersaing. Penelitian ini diharapkan dapat dijadikan pertimbangan bagi pelaku UMKM bahwa keunggulan bersaing dapat dicapai apabila di dalam menjalankan usahanya pelaku UMKM menerapkan pengelolaan keuangan yang baik, mempunyai strategi pemasaran yang baik, dan memiliki jiwa kewirausahaan yang tinggi.
\end{abstract}

Kata Kunci: jiwa kewirausahaan, keunggulan bersaing pengelolaan keuangan, strategi pemasaran

Abstract

This study aims to analyze the effect of financial management and marketing strategies on competitive advantage and to analyze the moderation effect of entrepreneurial spirit on the effect of marketing strategies and financial management on competitive advantage. The sample consisted of 76 MSMEs in Denpasar taken by simple random sampling. Research data were analyzed using Moderated Regression Analysis. Results showed that financial management and marketing strategies influenced competitive advantage and that entrepreneurial spirit strengthened the influence of financial management and marketing strategies on competitive advantage. Results of this study imply that to achieve a competitive advantage, MSMEs should have good financial management, marketing strategies, and high entrepreneurial spirit.

Keywords: $\quad$ competitive advantage, entrepreneurship, financial management, marketing strategy 


\section{Pendahuluan}

Usaha Mikro Kecil Menengah (UMKM) sangat berperan penting dalam perekonomian Indonesia. Keberadaan UMKM di Indonesia diperhatikan oleh pemerintah karena UMKM mampu menampung banyak tenaga kerja serta merupakan sumber penghasilan bagi masyarakat golongan ekonomi menengah kebawah. Pemerintah selalu berusaha mengupayakan perkembangan UMKM. Upaya yang dilakukan oleh pemerintah diantaranya adalah menetapkan bahwa dalam meratakan hasil pembangunan, UMKM diberikan kesempatan untuk mengatur dan mengembangkan usahanya, meningkatkan permodalan, meningkatkan keterampilan serta membantu dalam pemasaran produknya (Herleni \& Tasman, 2019).

Perhatian dari pemerintah sangat penting bagi perkembangan UMKM. Selain itu perilaku dari pelaku usaha juga sangat mempengaruhi keberadaan UMKM tersebut. Pelaku UMKM harus memperhatikan kinerja usahanya agar dapat bertahan dan unggul dalam persaingan. Perkembangan UMKM tidak selalu berjalan mulus. Kadang ada saja hambatan yang dialami oleh pelaku UMKM dalam mencapai keunggulan bersaing. Beberapa kendala yang dihadapi oleh UMKM dalam mencapai keunggulan bersaing antara lain terkait dengan pemasaran, penggelolaan keuangan usaha dan jiwa kewirausahaan yang dimilikinya.

Kesuksesan individu di dalam mengelola bisnisnya dipengaruhi oleh pengetahuan yang dimiliki. Wirausahawan setidaknya mempunyai pengetahuan tentang mengelolaan keuangan yang baik sehingga mampu menghasilkan keputusan investasi yang tepat bagi kelangsungan hidup usahanya (Sari \& Dwirandra, 2015). Pelaku wirausaha harus mampu dan paham membuat catatan transaksi keuangan dan membuat laporan keuangan secara sistematis dan teratur karena mereka tidak mungkin dapat mengingat semua transaksi keuangan yang terjadi pada usahanya. Dalam kenyataan di masyarakat masih banyak wirausahawan khususnya pengusaha mikro kecil belum memanfaatkan proses akuntansi dalam menjalankan usahanya dan mereka beranggapan bahwa hal itu tidak terlalu penting untuk dilakukan (Juniariani \&
Wirakusuma, 2016). Dalam mengelola sebuah usaha perlu pengelolaan keuangan yang baik sehingga akan menghasilkan kinerja yang baik pula. Jika pengelolaan keuangan semakin baik maka kinerja UMKM akan semakin bagus (Wahyudiati \& Isroah, 2018).

Pelaku UMKM dituntut untuk peka terhadap lingkungan agar mampu unggul dalam bersaing. UMKM akan sulit untuk berkembang jika pelakunya tidak paham cara memasarkan produk usahanya dengan baik (Suindari \& Juniariani, 2020). UMKM harus selalu berinovasi dan berkreatifitas dalam memasarkan produknya. Strategi pemasaran berpengaruh positif pada kinerja UMKM (Purwidianti \& Rahayu, 2015). Semakin bagus teknik pemasaran yang dilakukan maka UMKM akan mampu mencapai keunggulan dalam bersaing. Namun penelitian yang dilakukan oleh Krisdanti (2016) menemukan bahwa kreativitas dan inovasi tidak berpengaruh pada kinerja UMKM (Krisdanti \& Rodhiyah, 2016).

Strategi pemasaran dan pengelolaan keuangan yang baik akan membuat UMKM unggul dalam persaingan. Selain itu pelaku UMKM juga dituntut untuk memiliki jiwa kewirausahaan yang tinggi. Jiwa kewirausahaan yang dimiliki oleh pelaku UMKM akan mempengaruhi perilakunya dalam membuat keputusankeputusan dalam pengembangan usahanya. Seseorang yang memiliki jiwa kewirausahaan dalam dirinya akan mampu melihat peluang, mengumpulkan sumber daya yang dibutuhkan dan mengambil keuntungan tepat demi kesuksesan usahanya (Juniariani \& Wirakusuma, 2016). Orientasi kewirausahaan memiliki pengaruh besar terhadap keunggulan bersaing UMKM (Sulistyawati et al., 2018). Seseorang dengan jiwa kewirausahaan yang tinggi akan mencari segala informasi untuk mengembangkan usahanya dan akan melakukan perbaikan-perbaikan untukmencapai keunggulan dalam persaingan.

Dilihat dari uraian latar belakang yang disajikan, maka tujuan penelitian ini adalah untuk menganalisis pengaruh pengelolaan keuangan dan strategi pemasaran pada keunggulan bersaing serta untuk menganalisis moderasi jiwa kewirausahaan pada hubungan pengelolaan keuangan dan strategi pemasaran dengan keunggulan bersaing. Penelitian ini 
diharapkan mampu memberikan pertimbangan bagi pelaku UMKM bahwa pesatnya perkembangan jumlah UMKM menuntut pelaku usahanya untuk mampu bertahan dan bersaing. UMKM harus mampu menjalankan usahanya dengan baik dan memperhatikan faktor-faktor yang mempengaruhi kemajuan usahanya sehingga mampu untuk bertahan dan unggul dalam persaingan.

Penelitian ini mengunakan theory of planned behavior sebagai grand theory karena pelaku UMKM dalam menentukan perilakunya dipengaruhi oleh sikap awal yang dimiliki dan didukung oleh pengetahuannya dalam menjalankan usaha. Apabila pelaku UMKM dengan sungguh-sungguh memanfaatkan potensi diri yang ada untuk berperilaku dalam hal ini menjalankan usahanya maka usahanya akan berkembang dan mampu unggul dalam persaingan.

Keuangan usaha yang dikelola dengan baik akan menghasilkan informasi keuangan yang dapat digunakan dalam pengambilan keputusan. Sehingga keputusan yang diambil tepat dan sangat membantu dalam pengembangan usaha. Anggraeni dalam penelitiannya menyatakan bahwa pengelolaan keuangan yang profesional akan membantu wirausahawan dalam pengelolaan usaha dimulai dari membuat anggaran, perencanaan simpanan dana usaha serta informasi keuangan dasar untuk mencapai tujuan perusahaan (Anggraeni, 2015). Sari dan Dwirandra (2015) dalam penelitiannya menemukan bahwa pengetahuan akuntansi berpengaruh positif pada penggunaan informasi akuntansi dalam pembuatan keputusan investasi. Jika pelaku UMKM mempunyai kemampuan mengelola keuangan yang baik maka pelaku UMKM ini akan semakin yakin dalam membuat keputusan bagi kelangsungan usahanya di masa depan. Akan semakin yakin dalam mengambil keputusankeputusan yang mendorong UMKM mencapai keunggulan dalam persaingan. Berdasarkan hal tersebut, hipotesis penelitian dinyatakan sebagai berikut:

\section{$\mathrm{H}_{1}$ : Pengelolaan keuangan berpengaruh positif} pada keunggulan bersaing.

Agar unggul dalam persaingan pelaku UMKM dituntut untuk selalu berinovasi dan mengeluarkan ide-ide yang menarik serta unik dalam menyusun strategi pemasaran agar menghasilkan kinerja usaha yang bagus. Sebuah UMKM akan sulit untuk berkembang jika pelaku usahanya tidak paham bagaimana caranya memasarkan suatu produk, bagaimana caranya memperkenalkan produknya kepada pasar atau calon konsumen (Suindari \& Juniariani, 2020). Strategi pemasaran berpengaruh positif pada kinerja UMKM (Purwaningsih \& Kusuma, 2015). Strategi pemasaran yang bagus akan membuat UMKM tersebut berhasil mencapai keunggulan dalam persaingan. Berdasarkan hal tersebut, maka hipotesis penelitian dinyatakan sebagai berikut:

$\mathrm{H}_{2}$ : Strategi pemasaran berpengaruh positif pada keunggulan bersaing

Individu dengan jiwa kewirausahaan yang tinggi cenderung memilih cara bersaing yang berbeda. Mereka akan mencari berbagai macam informasi yang dapat digunakan untuk memajukan usahanya. Hasil penelitian Sari dan Dwirandra (2015) menunjukkan bahwa sifat kepribadian wirausaha memiliki pengaruh positif terhadap penggunaan informasi akuntansi. Hasil penelitian Juniariani dan Wirakusuma (2016) juga menyatakan bahwa kepribadian wirausaha berpengaruh terhadap penggunaan informasi akuntansi dalam pengambilan keputusan investasi. Seorang wirausahawan tentu membutuhkan suatu acuan untuk membuat keputusan pengembangan usahanya. Acuan yang digunakan adalah sebuah informasi keuangan yang mampu menunjukkan keadaan dari usaha yang sedang dijalaninya. Semakin tinggi jiwa kewirausahaan yang dimiliki oleh seseorang maka akan mendorongnya untuk menerapkan pengelolaan keuangan usaha yang baik yang dapat menunjang perkembangan usahanya dan mampu membuat usahanya unggul dalam persaingan. Berdasarkan hal tersebut, maka 
hipotesis penelitian dinyatakan sebagai berikut:

$\mathrm{H}_{3}$ : Jiwa kewirausahaan memoderasi pengaruh pengelolaan keuangan pada keunggulan bersaing.

Individu dengan jiwa kewirausahaan yang tinggi selalu ingin membuat usahanya berkembang pesat. Salah satu cara untuk mengembangkan usahanya adalah dengan menerapkan strategi pemasaran yang baik. Semakin bagus strategi pemasaran UMKM maka kinerja UMKM akan semakin meningkat. Jiwa kewirausahaan yang tinngi yang dimiliki oleh pelaku UMKM akan mendorong mereka untuk berusaha mencari informasi dan melakukan observasi agar dapat membuat strategi pemasaran yang tepat guna memajukan usahanya dan tentunya akan mampu membuat usahanya unggul dalam persaingan. Berdasarkan hal tersebut, maka hipotesis penelitian dinyatakan sebagai berikut:

$\mathrm{H}_{4}$ : Jiwa kewirausahaan memoderasi pengaruh strategi pemasaran pada keunggulan bersaing.

\section{Metodologi}

Penelitian ini dilakukan pada pelaku UMKM industri kreatif yang berada di Kota Denpasar. Dipilihnya UMKM Kota Denpasar karena Kota Denpasar merupakan sentral perekonomian di Bali. Menurut jenisnya, penelitian ini menggunakan jenis data kualitatif yaitu persepsi pelaku UMKM terhadap pengelolaan keuangan, strategi pemasaran, jiwa kewirausahaan dan keunggulan bersaing. Sedangkan menurut sumbernya, penelitian ini menggunakan data primer yaitu jawabanjawaban dari pelaku UMKM atas pertanyaan dalam kuesioner yang diberikan dan dikumpulkan dengan menggunakan metode survei. Responden yang digunakan dalam penelitian ini adalah UMKM industri kreatif yang merupakan UMKM binaan Dinas Koperasi Kota Denpasar. Dalam penelitian ini yang dikategorikan sebagai industri kreatif adalah UMKM yang memproduksi kerajinan (industri kerajinan) berjumlah 322 unit usaha. Pengambilan sampel dalam penelitian ini dihitung menggunakan Rumus Slovin, dengan taraf kesalahan $10 \%$.

$$
\begin{aligned}
n & =\frac{322}{1+322(0,10)^{2}}=76,30 \\
& =76 \text { (dibulatkan) }
\end{aligned}
$$

Berdasarkan perhitungan diatas, sampel yang digunakan dalam penelitian ini berjumlah 76 pelaku UMKM. Kemudian sampel dipilih atau ditentukan dengan menggunakan teknik simple random sampling.

Selanjutnya untuk menguji hubungan antar variabel penelitian ini menggunakan teknik analisis yaitu Moderated Regression Analysis (MRA), karena penelitian ini ingin menguji interaksi antara dua variabel utama serta sebuah variabel moderasi. Namun sebelumnya dilakukan pengujian asumsi klasik untuk mengetahui apakah model regresi layak untuk digunakan.

\section{Hasil dan Pembahasan}

Kuesioner dibagikan langsung kepada pelaku UMKM yang dijadikan sampel penelitian. Dari 76 kuesioner yang dibagikan hanya 63 kuesioner yang dapat diolah karena 13 kuesioner lainnya tidak diisi secara lengkap.

\section{Statistik Deskriptif}

Hasil statistik deskriptif terhadap variabel penelitian disajikan pada tabel 1 berikut ini:

Tabel 1. Uji Statistik Deskriptif

\begin{tabular}{cccc}
\hline Variabel & Max & Mean & Std. Deviation \\
\hline $\mathrm{X}_{1}$ & 30,00 & 28,199 & 1,961 \\
$\mathrm{X}_{2}$ & 28,00 & 26,484 & 2,837 \\
$\mathrm{X}_{3}$ & 39,00 & 31,637 & 3,393 \\
$\mathrm{Y}$ & 49,00 & 35.870 & 3,737 \\
\hline
\end{tabular}

Sumber: data diolah, 2020

Berdasarkan Tabel 1 dapat dijelaskan sebagai berikut:

1) Nilai maksimum dari variabel pengelolaan keuangan $\left(X_{1}\right)$ sebesar 30,00 . Nilai rata-rata sebesar 28,199 ini menunjukkan jawaban responden cenderung mengarah ke nilai tertinggi, dengan standar deviasi adalah 1,961. sehingga dapat disimpulkan bahwa data sampel semakin menyebar atau bervariasi. 
2) Nilai maksimum dari variabel strategi pemasaran $\left(\mathrm{X}_{2}\right)$ sebesar 28,00. Nilai ratarata sebesar 26,484 ini menunjukkan jawaban responden cenderung mengarah ke nilai tertinggi, dengan standar deviasi adalah 2,837. Sehingga dapat disimpulkan bahwa data sampel semakin menyebar atau bervariasi.

3) Nilai maksimum dari variabel jiwa kewirausahaan $\left(\mathrm{X}_{3}\right)$ sebesar 39,00. Nilai rata-rata sebesar 31,637 ini menunjukkan jawaban responden cenderung mengarah ke nilai tertinggi, dengan standar deviasi adalah 3,393. Sehingga dapat disimpulkan bahwa data sampel semakin menyebar atau bervariasi.

4) Nilai maksimum dari variabel keunggulan bersaing (Y) sebesar 49,00. Nilai rata-rata sebesar 35,870 ini menunjukkan jawaban responden cenderung mengarah ke nilai tertinggi, dengan standar deviasi adalah 3,737. Sehingga dapat disimpulkan bahwa data sampel semakin menyebar atau bervariasi.

\section{Teknik Analisis Data}

Teknik analisis yang digunakan untuk pengujian hipotesis dalam penelitian ini adalah Moderated Regression Analysis (MRA). Namun sebelumnya dilakukan pengujian intrumen untuk mengetahui valid dan reliabelnya setiap butir pertanyaan kuisioner dan serta melakukan pengujian asumsi klasik. Setelah uji instrumen dan uji asumsi klasik terpenuhi maka selanjutnya dilakukan pengujian hipotesis dengan menggunakan Moderated Regression Analysis (MRA).

Tabel 2. Hasil Analisis Regresi Moderasi

\begin{tabular}{lcc}
\hline Variabel & $\begin{array}{c}\text { Standardized } \\
\text { Coefficient } \\
\text { Beta }\end{array}$ & Sig. \\
\hline Constant & & 0,032 \\
X1 & 0,844 & 0,032 \\
X2 & 0,536 & 0,048 \\
X3 & 0,689 & 0,001 \\
X1_X3 & 0,178 & 0,003 \\
X2_X3 & 0,327 & 0,021 \\
\hline
\end{tabular}

Sumber: data diolah, 2020.
Berdasarkan Tabel 2, maka persamaan regresi dapat dibuat sebagai berikut:

$\mathrm{Y}=0,844 \mathrm{X}_{1}+0,536 \mathrm{X}_{2}+0,689 \mathrm{X}_{3}+0,178 \mathrm{X}_{1} \mathrm{X}_{3}+$ $0,327 \mathrm{X}_{2} \mathrm{X}_{3}+\varepsilon$

Nilai koefisien regresi pengelolaan keuangan $\left(\mathrm{X}_{1}\right)$ 0,844, ini berarti bahwa jika pengelolaan keuangan mengalami peningkatan maka keunggulan bersaing akan meningkat. Nilai koefisien regresi strategi pemasaran $\left(\mathrm{X}_{2}\right)$ 0,536, ini berarti bahwa jika strategi pemasaran meningkat maka keunggulan bersaing akan mengalami peningkatan. Nilai koefisien regresi jiwa kewirausahaan $\left(\mathrm{X}_{3}\right)$ 0,689 , ini berarti bahwa jika jiwa kewirausahaan meningkat maka keunggulan bersaing akan meningkat. Nilai koefisien regresi interaksi pengelolaan keuangan dan jiwa kewirausahaan 0,178 , ini berarti bahwa jiwa kewirausahaan memperkuat pengaruh pengelolaan keuangan pada keunggulan bersaing. Dan nilai koefisien regresi interaksi strategi pemasaran dengan jiwa kewirausahaan 0,327 , ini berarti bahwa jiwa kewirausahaan memperkuat pengaruh strategi pemasaran pada keunggulan bersaing.

Hipotesis pertama menyatakan bahwa pengelolaan keuangan berpengaruh positif pada keunggulan bersaing. Berdasarkan Tabel 2 , dapat dilihat bahwa hasil uji t terhadap variabel pengelolaan keuangan $\left(\mathrm{X}_{1}\right)$ diperoleh nilai signifikansi $t$ sebesar 0,032 dan nilai koefisien regresi (Beta) positif 0,844. Nilai signifikansi pengelolaan keuangan sebesar $0,032<0,05$ maka $\mathrm{H}_{1}$ diterima. Hal ini berarti pengelolaan keuangan berpengaruh positif pada keunggulan bersaing. Semakin bagus pengelolaan keuangan usaha yang dilakukan oleh pelaku UMKM maka akan semakin unggul dalam persaingan. Keuangan usaha yang dikelola dengan baik akan menghasilkan informasi keuangan yang dapat digunakan dalam pengambilan keputusan. Sehingga keputusan yang diambil tepat dan sangat membantu dalam pengembangan usaha. Penelitian ini sejalan dengan penelitian yang dilakukan oleh Anggraeni (2015) yang menyatakan bahwa pengelolaan keuangan yang profesional akan membantu wirausahawan dalam mengelola usahanya dimulai dari membuat anggaran, perencanaan simpanan dana usaha serta informasi keuangan dasar untuk mencapai tujuan 
perusahaan. Demikian juga penelitian yang dilakukan oleh Sari dan Dwirandra (2015) yang menemukan bahwa pengetahuan akuntansi berpengaruh positif pada penggunaan informasi akuntansi dalam pembuatan keputusan investasi. Jika seorang pelaku UMKM memiliki pengetahuan tentang mengelola keuangan yang baik maka pelaku UMKM ini akan semakin yakin dalam membuat keputusan investasi bagi kelangsungan usahanya di masa depan. Akan semakin yakin dalam mengambil keputusan-keputusan yang mendorong UMKM mencapai keunggulan bersaing.

Hipotesis kedua menyatakan bahwa strategi pemasaran berpengaruh positif pada keunggulan bersaing. Berdasarkan Tabel 2, dapat dilihat bahwa hasil uji $t$ terhadap variabel strategi pemasaran $\left(\mathrm{X}_{2}\right)$ diperoleh nilai signifikansi $t$ sebesar 0,048 dan nilai koefisien regresi (Beta) positif 0,536. Nilai signifikansi strategi pemasaran sebesar 0,048< 0,05 maka $\mathrm{H}_{2}$ diterima. Hal ini berarti strategi pemasaran berpengaruh positif pada keunggulan bersaing. Semakin bagus strategi pemasaran usaha yang diterapkan oleh pelaku UMKM maka akan semakin unggul dalam persaingan. Agar unggul dalam persaingan pelaku UMKM dituntut untuk selalu berinovasi dan mengeluarkan ide-ide yang menarik serta unik dalam menyusun strategi pemasaran agar menghasilkan kinerja usaha yang bagus. Penelitian ini sejalan dengan penelitian yang dilakukan oleh Purwaningsih dan Kusuma (2015) dan Purwidianti (2015) yang dalam penelitianya menemukan bahwa strategi pemasaran berpengaruh positif pada kinerja UMKM. Dengan menerapkan strategi pemasaran yang bagus, produk dari UMKM tersebut akan dikenal oleh pasar dan apalagi ditambah dengan kualitas produk yang baik maka produk dari UMKM tersebut akan dicari dan diminati oleh pasar. Strategi pemasaran yang bagus akan membuat UMKM tersebut berhasil mencapai keunggulan bersaing.

Hipotesis ketiga menyatakan bahwa jiwa kewirausahaan memperkuat pengaruh pengelolaan keuangan pada keunggulan bersaing. Berdasarkan Tabel 5, dapat dilihat bahwa hasil koefisien interaksi variabel pengelolaan keuangan $\left(\mathrm{X}_{1}\right)$ dan jiwa kewirausahaan $\left(\mathrm{X}_{3}\right)$ diperoleh nilai signifikansi t sebesar 0,003 dan nilai koefisien regresi (Beta) positif 0,178. Nilai signifikansi sebesar $0,003<0,05$ maka $\mathrm{H}_{3}$ diterima. Hal ini berarti jiwa kewirausahaan memperkuat pengaruh pengelolaan keuangan pada keunggulan bersaing. Jiwa kewirausahaan yang dimiliki oleh pelaku UMKM akan mendorong mereka untuk mengambil sikap untuk menerapkan pengelolaan keuangan yang baik bagi usahanya dan hal itu akan membuat UMKM tersebut mampu unggul dalam persaingan. Seorang wirausaha yang memiliki jiwa kewirausahaan yang tinggi cenderung akan berusaha menjaga kelangsungan usahanya dan memilih cara bersaing yang berbeda untuk mencapai keunggulan bersaing. Mereka akan mencari berbagai macam informasi yang dapat digunakan untuk memajukan usahanya.

Hasil penelitian ini mendukung penelitian yang dilakukan oleh Sari dan Dwirandra (2015) serta penelitian Juniariani dan Wirakusuma (2016) yang menyatakan bahwa jiwa kewirausahaan berpengaruh terhadap penggunaan informasi akuntansi dalam pengambilan keputusan investasi. Seorang wirausahawan tentu membutuhkan suatu acuan untuk membuat keputusan pengembangan usahanya. Acuan yang digunakan adalah sebuah informasi keuangan yang mampu menunjukkan keadaan dari usaha yang sedang dijalaninya. Dengan pengelolaan keuangan yang baik akan menghasilkan informasi keuangan yang dapat digunakan sebagai acuan atau dasar membuat keputusan yang tepat bagi kelangsungan usaha UMKM. Semakin tinggi jiwa kewirausahaan yang dimiliki oleh seseorang maka akan mendorongnya untuk menerapkan pengelolaan keuangan usaha yang baik yang dapat menunjang perkembangan usahanya dan mampu membuat usahanya unggul dalam persaingan.

Hipotesis keempat menyatakan bahwa jiwa kewirausahaan memperkuat pengaruh strategi pemasaran pada keunggulan bersaing. Berdasarkan Tabel 5, dapat dilihat bahwa hasil koefisien interaksi variabel strategi pemasaran $\left(X_{2}\right)$ dan jiwa kewirausahaan $\left(X_{3}\right)$ diperoleh nilai signifikansi $t$ sebesar 0,021 dan nilai koefisien regresi (Beta) positif 0,327. Nilai

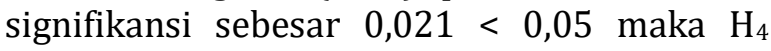
diterima. Hal ini berarti jiwa kewirausahaan 
memperkuat pengaruh strategi pemasaran pada keunggulan bersaing. Jiwa kewirausahaan yang dimiliki oleh pelaku UMKM akan mendorong mereka untuk menerapkan strategi pemasaran yang baik agar usahanya semakin dikenal oleh pasar dan mampu membuat usahanya unggul dalam persaingan. Seorang wirausahawan yang memiliki jiwa kewirausahaan selalu ingin membuat usahanya berkembang pesat. Salah satu cara untuk mengembangkan usahanya adalah dengan menerapkan strategi pemasaran yang baik. Semakin bagus strategi pemasaran UMKM maka kinerja UMKM akan semakin meningkat. Semakin tinggi jiwa kewirausahaan yang dimiliki oleh pelaku UMKM maka ia akan berusahasa mencari informasi dan melakukan observasi agar dapat membuat strategi pemasaran yang tepat guna memajukan usahanya dan tentunya akan mampu membuat usahanya unggul dalam persaingan.

\section{Kesimpulan}

Kesimpulan dari penelitian ini adalah pengelolaan keuangan berpengaruh positif pada keunggulan bersaing. Hal ini menunjukkan bahwa semakin baik pengelolaan keuangan yang dilakukan oleh UMKM dalam menjalankan usahanya maka UMKM tersebut akan mampu mencapai keunggulan dalam persaingan. Strategi pemasaran juga berpengaruh positif pada keunggulan bersaing artinya semakin bagus strategi pemasaran usaha yang diterapkan oleh pelaku UMKM maka akan membuat UMKM tersebut berhasil mencapai keunggulan bersaing. Jiwa kewirausahaan memperkuat pengaruh pengelolaan keuangan pada keunggulan bersaing. Hal ini menunjukkan bahwa jiwa kewirausahaan yang dimiliki oleh pelaku UMKM akan mendorong mereka untuk mengambil sikap untuk menerapkan pengelolaan keuangan yang baik bagi usahanya dan hal itu akan membuat UMKM tersebut mampu unggul dalam persaingan. Jiwa kewirausahaan memperkuat pengaruh strategi pemasaran pada keunggulan bersaing. Hal ini menunjukkan bahwa jiwa kewirausahaan yang dimiliki oleh pelaku UMKM akan mendorong mereka untuk menerapkan strategi pemasaran yang baik agar usahanya semakin dikenal oleh pasar dan mampu membuat usahanya unggul dalam persaingan.

Dari hasil penelitian ini diharapkan menjadi pertimbangan bagi akademisi khususnya Fakultas Ekonomi agar lebih memperhatikan kualitas pembelajaran yang diberikan kepada mahasiswa. Terutama mata kuliah akuntansi, kewirausahaan dan manajemen pemasaran agar mahasiswa bisa memahami bagaimana cara menjalankan dan mengelola sebuah usaha dengan baik dan menumbuhkan jiwa kewirausahaan di dalam dirinya dimana hal itu bisa mereka gunakan sebagai bekal saat terjun ke masyarakat dan menjalankan sebuah usaha untuk masa depannya. Bagi praktisi yaitu pelaku UMKM agar mampu menumbuhkan dan mengembangkan jiwa kewirausahaan didalam dirinya dan harus mampu mengelola keuangan usahanya dengan baik serta lebih kreatif dan inovatif dalam menyusun strategi pemasaran sehingga usahanya akan semakin berkembang dan mampu unggul di dalam persaingan.

\section{Daftar Referensi}

Anggraeni, B. D. (2015). Pengaruh Tingkat Literasi Keuangan Pemilik Usaha Terhadap Pengelolaan Keuangan. Studi Kasus: UMKM Depok. Jurnal Vokasi Indonesia, 3(2), 109-121.

Ghozali, I. (2016). Aplikasi Analisis Multivariate dengan Program SPSS. Edisi ke-7. Semarang: Universitas Diponegoro

Herleni, S., \& Tasman, A. (2019). Pengaruh Financial Knowledge dan Internal Locus Of Control Terhadap Personal Financial Management Behaviour Pelaku Umkm Kota Bukittinggi. Jurnal Kajian Manajemen dan Wirausaha, 01(01), 270-275.

Juniariani, N. M. R., \& Wirakusuma, M. G. (2016). Pengaruh Pengetahuan Akuntansi dan Jiwa Kewirausahaan Pada Penggunaan Informasi Akuntansi Dalam Pembuatan Keputusan Investasi. Jurnal Buletin Studi Ekonomi, 21(2), 161-171.

Krisdanti, G., \& Rodhiyah. (2016). Analisis FaktorFaktor Yang Mempengaruhi Kinerja UKM Pada Sektor Industri Pengolahan Makanan di Kota Semarang. Jurnal Ilmu Administrasi Bisnis, 5(4). 
Purwaningsih, R., \& Kusuma Damar, P. (2015). Analisis Faktor-Faktor Yang Mempengaruhi Kinerja Usaha Kecil Dan Menengah (Ukm) Dengan Metode Structural Equation Modeling (Studi kasus UKM berbasis Industri Kreatif Kota Semarang). E-Journal Undip, 1(1), 7-12. https://publikasiilmiah.unwahas.ac.id/index.p $\mathrm{hp} /$ prosiding_snst_ft/article/view/1113.

Purwidianti, W., \& Rahayu, T. S. M. (2015). Pengaruh Faktor Internal dan Eksternal Terhadap Kinerja Usaha Industri Kecil dan Menengah di Purwokerto Utara. KINERJA, 19(1), 149-159.

Sari, N. M. A. M., \& Dwirandra, A. (2015). Pengaruh Kepribadian Wirausaha Dan Pengetahuan Akuntansi Pada Penggunaan Informasi Akuntansi Dalam Pembuatan Keputusan Investasi. E-Jurnal Akuntansi, 11(1), 303-319.

Suindari, N. M., \& Juniariani, N. M. R. (2020). Pengelolaan Keuangan, Kompetensi Sumber Daya Manusia Dan Strategi Pemasaran Dalam Mengukur Kinerja Usaha Mikro Kecil Menengah ( Umkm ). Krisna Kumpulan Riset Akuntansi, 11(2), 148-154.

Sulistyawati, A. I., Indarto, \& Saifudi. (2018). Beberapa Faktor yang Mempengaruhi Keunggulan Bersaing pada UMKM Handycraft di Semarang. Prosiding Seminar Nasional Unimus, 1, 307-315.

Wahyudiati, D., \& Isroah. (2018). Pengaruh Aspek Keuangan Dan Kompetensi Sumber Daya Manusia (Sdm) Terhadap Kinerja Usaha Mikro Kecil Dan Menengah (Umkm) Di Desa Kasongan. Jurnal Profita, 2, 1-11. 